\title{
A study to assess the impact of education intervention on the knowledge regarding hazards of plastic food containers in school children
}

\author{
Angelin Priya*, Manju Toppo, Daneshwar Singh, Nisha Singh, Soumitra Sethia
}

Department of Community Medicine, Gandhi Medical College, Bhopal, Madhya Pradesh, India

Received: 21 June 2016

Accepted: 12 July 2016

\author{
*Correspondence: \\ Dr. Angelin Priya, \\ E-mail: dr.angelinpriya@gmail.com
}

Copyright: () the author(s), publisher and licensee Medip Academy. This is an open-access article distributed under the terms of the Creative Commons Attribution Non-Commercial License, which permits unrestricted non-commercial use, distribution, and reproduction in any medium, provided the original work is properly cited.

\begin{abstract}
Background: One among the most hazardous manufacture is the plastic. It has become a part of every aspect of human living. When any food material or water is stored in the plastic containers the small, measurable amounts of the materials may migrate into food and can be consumed with it through the process of leaching. Leaching means that some of the chemicals of the plastic enter the food material or water. BPA is a structural component in polycarbonate beverage bottles. Objectives were to assess the knowledge regarding safe use of Plastics and to assess the impact of educational intervention given to them.

Methods: Study design-Community based educational intervention study. Study Subjects - 300 school students of standard 7-9 and 11 of two private school of Bhopal.

Results: Out of 300 students, $56 \%$ used plastics in the form of tiffin and water bottle, $37.33 \%$ used in the form of Water Bottles only and $6.66 \%$ did not use Plastic in the form of anything. The knowledge of the respondents increased after the educational intervention and the difference was found to be significant $(\mathrm{P}<0.001)$ shows that the mean percent of knowledge score of plastics was $53 \%$ which increased significantly to $75 \%$ after health education intervention, $<0.05$.

Conclusions: Children are amenable to correction, so any health education imparted is most likely to result in change in their behavior and practice.
\end{abstract}

Keywords: Plastic, Polycarbonate, Bisphenol A, Education intervention

\section{INTRODUCTION}

The use of chemicals has increased dramatically due to the economic development in various sectors including industry, agriculture and transport. ${ }^{1}$ A significant negative effect is the increasing incidents of illness like cancers, birth defects and many more, many of these are due to the varieties of chemicals exposure either a result of direct or indirect form, as a consequence, people are exposed to a large number of chemicals. ${ }^{2}$ Exposure occurs through the air they breathe, the water they drink or bathe in, the food they eat, and the soil they touch (or ingest as toddlers). One among the most hazardous manufacture is the plastic. It has become a part of every aspect of human living. ${ }^{4}$ When any food material or water is stored in the plastic containers the small, measurable amounts of the materials may migrate into food and can be consumed with it through the process of leaching. ${ }^{5}$ Leaching means that some of the chemicals of the plastic enter the food material or water. BPA is a structural component in polycarbonate beverage bottles. It is also a component in metal can coatings, which protect the food from directly contacting metal surfaces. Though BPA is Bisphenol A (BPA) has been heightened interest in the safe use of plastic bottles or containers in food packaging 
has resulted in increased public awareness as well as scientific interest. As a result, many exploratory scientific studies have appeared in the public literature which advocates harmful effects of BPA. ${ }^{7-11}$ It has been well characterized as an endocrine disruptor which can mimic the body's own hormones potentially leading to a variety of health outcomes such as breast and prostate cancer, menstrual irregularities, genital abnormalities in male babies, infertility in men and women, early puberty in girls, and metabolic disorders such as skin disorders, increasing neurobehavioral problems, obesity ,type 2 diabetes, and immune system effects. ${ }^{12-14}$ Use of plastic bottles or containers for a long time and repeated washing increases the chances of leaching. ${ }^{15}$ Although not all plastics contain Bisphenol A. Though bureau of Indian standards has prepared a draft notification regarding banning BPA, not many are aware about it. ${ }^{16}$ The plasticizer Bisphenol A (BPA) is banned in baby bottles in many industrialized countries due to safety concerns. ${ }^{17,18}$ Children are more vulnerable to the illness because of exposure since childhood ${ }^{19,20}$. Use of plastic containers, bottles and other items by children has become common. The long lasting ill effects could be brought down through an awareness and modification of the life style at the early age of their life. However it could be only prevented rather responding at the falling stage. This could be possible through the education given to them in the school days. This issue seeks attention not only from the health point of view, but also environmental values attached to it. This study is therefore conducted with the aim of assessing the knowledge regarding safe use of plastics as food and water container in school students and to assess the change in action taken by the effect of educational intervention.

\section{METHODS}

This was a community based educational interventional study conducted in two private schools situated in the field practice area (ward no.8) of Gandhi Medical College, Bhopal. In these schools, students of standard 7 , 8,9 and 11 were only taken as it was expected that they would have a better understanding of the content of the intervention being given. The sample size of 300 was calculated using $95 \%$ confidence limits, $85 \%$ power and assuming the usage rate of plastic consumers to be $47 \%$ as reported in india. ${ }^{20}$ Convenient method of sampling is adopted. An educational intervention was given in the form of short lectures, demonstration imparted with audio-visual method in the mode of interactive session. Images and videos using you tube/Google which were in the open domains were liberally used in order to convey the intended messages (Figure 1 and 2- Glimpse of the Audio -Visual Method).

\section{Duration of study}

This study was undertaken from the month of January 2016 to March 2016 for a period of Three month.

\section{Inclusion criteria}

Those present on both the days, that is the day of intervention and the day when post intervention changes were assessed were only taken.

\section{Exclusion criteria}

Students of standard 10 and 12 were excluded because of their upcoming board exams. Students those who were not willing to participate and absent.

\section{Study tool}

A structured self-administrative questionnaire was developed by the researchers for data collection to fully meet the demands of this research. The developed questionnaire are corrected, revised and validated by public health experts. This tool contained Questionnaire includes the following component- information regarding their extent of plastic use, type of plastic being used and their knowledge about the plastics was used for data collection.

\section{Data collection and procedure}

After taking permission from the school authority, the class teachers were explained the purpose of the study and rapport was built up among them. Briefing was done to the students regarding the questionnaire provided to them. Care was taken to ensure privacy and confidentiality. Two month after the educational intervention, post test was conducted for the participants who attended the entire program. At the end of the study, all their queries were answered satisfactorily by the research team.

\section{Statistical analysis}

Data obtained were collated and analyzed statistically by simple proportions with the help of MS EXCEL 2007 and Epi info 7.

\section{RESULTS}

Mean age of 300 participants was $1.11 \pm 15.43$ years. Majority of them 186 (62\%) were males and 114 (38\%) were females. Among the participants 168 (56\%) used plastics in the form of tiffin, water bottle, $112(37.33 \%)$ used in the form of Water Bottles only and $20(6.66 \%)$ didn't use plastic in the form of anything. About 84 $(30 \%)$ of the children had polyethylene water bottles, 28 (10\%) had Polypropylene water bottles while $(1 \%)$ used bottles made up of Poly carbonate (Table 1).

$234(78 \%)$ out of 300 were aware of that plastics are dangerous for humans/planet, $183(63 \%)$ knew that plastics are non-biodegradable, $42(14 \%)$ do not prefer to eat or drink in plastic utensils or containers, , only $9(3 \%$ )of them knew about the leaching property of plastics and 
none of the participants knew about BPA (Table 2).The over-all mean knowledge comparison reveals that pre-test mean score was $1.78 \pm 1.6$ and mean post-test score was $2.8 \pm 0.98$. The significant difference was calculated by using students ' $t$ ' test with a value of 2.98. The knowledge of the respondents increased after the educational intervention and the difference was found to be significant which is relevant to the self-reported practices and the influence of educational intervention. From the study findings, it is concluded that there was a significant difference between the pretest and posttest knowledge scores on plastics.

The mean knowledge score during pre-test was $53 \%$ where as it was increased up to $75 \%$ during the post-test (t 2.98, df 1 and $\mathrm{p}<0.05$ ) as an effectiveness of structured teaching programme. The difference assessed was $22 \%$ (Table 3). Change in habits and practices take time, still there was significant change in Practice seen in the respondents (Table 3 ).

Table 1: Distribution of students according to age and type of plastics used by them.

\begin{tabular}{|ll|}
\hline Age & $\begin{array}{l}\text { Percentage } \\
(300)\end{array}$ \\
\hline 14 & 34.78 \\
\hline 15 & 24.75 \\
\hline 16 & 22.41 \\
\hline 17 & 18.06 \\
\hline $\begin{array}{l}\text { Type of plastics used as water bottles } \\
\text { by them }\end{array}$ & $\begin{array}{l}\text { Percentage } \\
(280)\end{array}$ \\
\hline $\begin{array}{l}\text { The name was wiped up by prolonged } \\
\text { use }\end{array}$ & $36 \%$ \\
\hline Not mentioned & $23 \%$ \\
\hline Polyethylene Terepthalate (PET) or 1 & $30 \%$ \\
\hline Polypropylene(PP) or 5 & $10 \%$ \\
\hline Polycarbonate(PC)or 7 & $1 \%$ \\
\hline
\end{tabular}

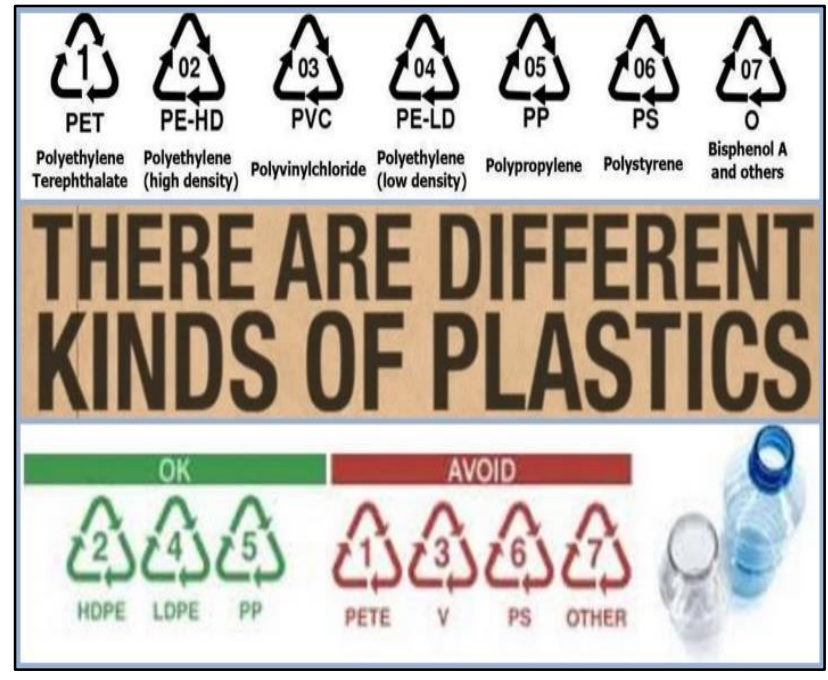

Figure 1: Glimpse of the audio -visual method ${ }^{35,36,38}$.

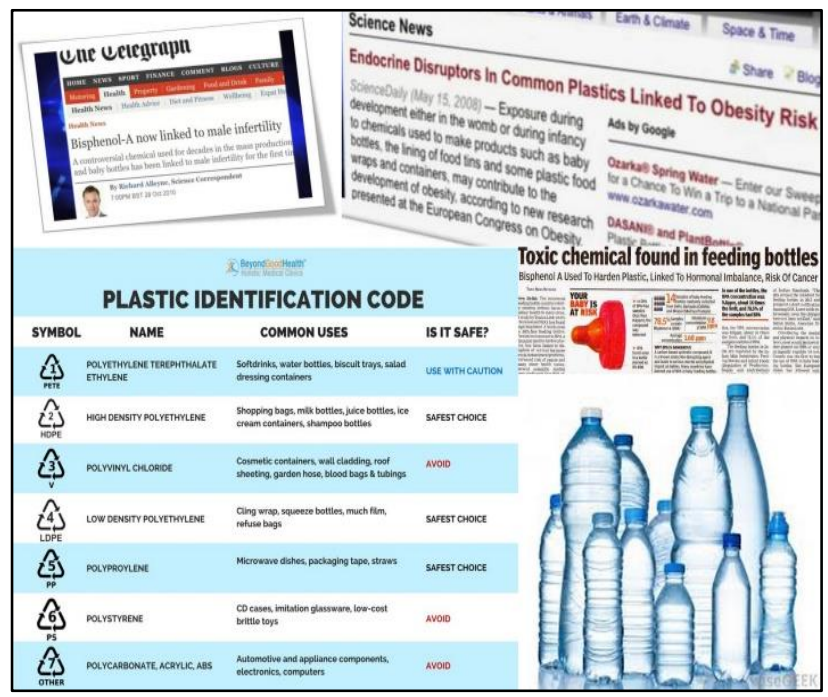

Figure 2: Glimpse of the audio-visual method ${ }^{37,39-41}$.

Table 2: Comparison of knowledge about hazards of plastic containers pre and post intervention.

\begin{tabular}{|c|c|c|c|c|}
\hline $\begin{array}{l}\text { Knowlege about Hazards of } \\
\text { Plastic }\end{array}$ & $\begin{array}{l}\text { Pre } \\
\text { interventional } \\
\mathrm{N}(\%)\end{array}$ & $\begin{array}{l}\text { Post } \\
\text { interventional } \\
\mathrm{N}(\%)\end{array}$ & $\begin{array}{l}\text { Chi Squared } \\
\text { value }\end{array}$ & P value \\
\hline $\begin{array}{l}\text { Do you think plastics are } \\
\text { dangerous for humans/planet }\end{array}$ & $234(78)$ & $294(98)$ & 56.818 & $\mathrm{P}<0.001$ \\
\hline $\begin{array}{l}\text { Plastics are non-degradable so is } \\
\text { a risk to our planet }\end{array}$ & $189(63)$ & $195(65)$ & 0.260 & $\mathrm{p}>0.5$ \\
\hline Have you heard of Bisphenol A & $9(3)$ & $267(89)$ & 361.229 & $\mathrm{P}<0.001$ \\
\hline $\begin{array}{l}\text { BPA is used to make what type } \\
\text { of Plastic }\end{array}$ & $0(0)$ & $162(54)$ & Fishers exact test & $\mathrm{P}<0.001$ \\
\hline $\begin{array}{l}\text { Should hot eatables/drink be put } \\
\text { into Plastic container }\end{array}$ & $42(14)$ & $249(83)$ & 285.917 & $\mathrm{P}<0.001$ \\
\hline
\end{tabular}


Table 3: Mean, SD, mean\% of the knowledge scores in pre-test and post-test $(n=5)$.

\begin{tabular}{|lllllll|}
\hline Mean \pm SD & Mean $\%$ & Mean \pm SD & Mean $\%$ & Efficacy & Efficacy $\%$ & Paired t \\
\hline Pre Intervention & Post Intervention & & & & \\
\hline $1.78 \pm 1.6$ & 53 & $2.8 \pm 0.98$ & 75 & 1.10 & 22 & $2.98, \mathrm{P}<0.05$ \\
\hline
\end{tabular}

Table 4: Comparison of practice of use of plastic containers pre and post intervention.

\begin{tabular}{|c|c|c|c|c|}
\hline $\begin{array}{l}\text { Practices regarding } \\
\text { Plastics }\end{array}$ & Pre Interventional N(\%) & $\begin{array}{l}\text { Post } \\
\text { interventional } \\
\mathbf{N}(\%)\end{array}$ & $\begin{array}{l}\text { Chi squared } \\
\text { value }\end{array}$ & $\begin{array}{l}\text { "P" } \\
\text { Value }\end{array}$ \\
\hline Use of Plastic Container & $279(93)$ & $75(25)$ & 286.730 & $<0.001$ \\
\hline $\begin{array}{l}\text { Use of Substitutes of } \\
\text { Plastic }\end{array}$ & $21(7)$ & $225(75)$ & 286.730 & $<0.001$ \\
\hline $\begin{array}{l}\text { Check the type of Plastic } \\
\text { before buying }\end{array}$ & 0 & $58(174)$ & 245.070 & $<0.001$ \\
\hline $\begin{array}{l}\text { Eat or drink in Plastic } \\
\text { Containers }\end{array}$ & $200(66.66)$ & $131(43.67)$ & 32.083 & $<0.001$ \\
\hline
\end{tabular}

\section{DISCUSSION}

Definitive evidence linking exposure to BPA and specific conditions are biased till date. However, some of the adverse effects in animal studies are observed at levels of exposure close to those in humans. On the basis of available evidences, it is prudent to recommend reduce BPA exposure and by taking sole responsibility of one's own health a healthy behavior can be achieved by modulating our thought, practices and perceptions with the tool of knowledge and awareness. While a lot is being said regarding learning life's lesson from children. Children can be instruments in imparting education to the adults. Children are amenable to correction, so any health education imparted is most likely to result in change in their behavior and practice. School children communicate knowledge to their friends, parents and relatives thus becoming a catalyst by improving their knowledge and practice. So, Why not begin with this mode of Primary intervention in the most productive group the schoolchildren. From the data analysis and findings of the study, it is revealed that educational intervention based on interactive educational approaches there was a significant increase in knowledge and behavior. Majority of the subjects $78 \%$ in this study was aware of health hazard of plastics. This was in the agreement with the result of other studies conducted in India and other parts of the world where $50 \%$ to $81.1 \%$ participants were aware of associated health hazards. ${ }^{22-25}$ In our study there was a significant $(\mathrm{P}<0.001)$ increase in knowledge after the educational intervention on hazards of plastic containers which was in accord with the study by Shrestha Ashutosh there was significant increase in knowledge and practice score of school children after health education intervention on hand washing. ${ }^{26}$ $(\mathrm{p}<0.05)$ Furthermore, other studies have confirmed that this interactive approach is effective in improving knowledge of participants. ${ }^{27-31}$ In our study the mean knowledge score of adults was $53 \%$ in the pre-test which increased to $75 \%$, with a difference of $22 \%$ at $\mathrm{P}<0.05$ with a paired $t$ value of 2.98 which was similar to the study conducted by Jincy Manuel et al in which the intervention on hazards of plastic waste and its disposal on adults in which the difference in the knowledge was assessed to be $37.96 \% .{ }^{32}$ Therefore the knowledge of the adults can be further improved by providing ongoing teaching and health education programmers. ${ }^{33}$ In a study by Sandeep K.R et al the effectiveness of the education intervention in knowledge regarding prevention Dengue was found to $42.58 \%$ in rural high school children showing the impact a teaching program can make on children and their knowledge. ${ }^{34}$ In our study the change in Practice was seen which was significant at $\mathrm{P}<$ 0.001 ,which was similar to the study on hand washing in which the change in practice of hand washing with soap was found to be significant, Such studies shows that anything taught to the children does not go vain .Such health education can be imparted to the children by implementing it in their curriculum, which will make them well informed about potential health problems in the community and the knowledge acquired would result in the development of healthy practice.

\section{CONCLUSION}

Plastic in our daily lives, it started as a carry bag and now has infiltrated our house, look up and you see it there, from its place in the living space, bathroom to the kitchen. it has cleverly crawled into our food, from being on the shelves storing grocery to serving food on the table. From children's Tiffin boxes to water bottles, from glasses to cups and baby feeding bottles. Most feeding bottles are sold liberally in the Indian market without any label to mention the BPA concentration found in the container. Instructional interventions based on interactive approaches can be useful, and applicable for behavior modification. This information may also result in the 
design of more effective intervention strategies for reducing the risks posed to children by harmful substances in then home. At this time, the possibility of adverse health effects arising from BPA cannot be ruled out definitively as the evidence remains uncertain. It is therefore important to follow directions when using plastics to store or cook food. Individuals can take conscious knowledge full practical steps of their own to reduce exposure to BPA and other chemicals associated with plastics, rather than become fearful about all the potential sources for exposure. The limitations of this study included the absence of a comparative group, the small sample size, because of resources and manpower constraints and the education intervention could have been given to parents, school teachers of children and also to expectant mothers who would eventually buy feeding bottles for their baby. Implications findings indicate future educational sessions may be warranted this educational program may benefit all disciplines.

\section{ACKNOWLEDGEMENTS}

We would like to sincerely thank our Professor and Head of Department Dr.D.K.Pal for granting permission to carry out this study. We would also extend our gratitude to the Principal and Teachers of the Schools where this study was done. Special thanks to the lovely participants for their co-operation.

\section{Funding: No funding sources}

Conflict of interest: None declared

Ethical approval: The study was approved by the Institutional Ethics Committee

\section{REFERENCES}

1. Available at: http://www.who.int/ ceh/ risks/ cehchemicals.

2. Rushton L. Health hazards and waste management. British Medical Bulletin. 2003;68(1):183-97.

3. WHO_SDE_PHE_02.06.pdf

4. Thompson RC, Moore CJ, vom Saal FS, Swan SH. Plastics, the environment and human health: current consensus and future trends. Philosophical Transactions of the Royal Society B: Biological Sciences. 2009;364(1526):2153-66.

5. National Industrial Chemicals Notification and Assessment Scheme (NICNAS), Draft Phthalate Hazard Assessments and Hazard Compendium, NICNAS, Editor. 2007, NICNAS.

6. Available at: http://www.fda.gov/NewsEvents/PublicHealthFocus /ucm064437.htm.

7. Saal V, Bisphenol AF. Developmental factors in adult obesity: diet, environmental chemicals and importance of animal models. Presentation available at http://www.pptox.dk/portals/0/23_slide.pdf.

8. Takeuchi T, Tsutsumi O, Ikezuki Y, Takai Y and Taketani Y. Positive relationship between androgen and the endocrine disruptor, bisphenol $\mathrm{A}$, in normal women and women with ovarian dysfunction. Endocr J. 2004;51:165-9.

9. Sugiura-Ogasawara M, Ozaki Y. Exposure to bisphenol A is associated with recurrent miscarriage. Hum Reprod. 2005;20(8):2325-9.

10. Hiroi H, Tsutsumi O, Takeuchi T. Differences in serum bisphenol a concentrations in premenopausal normal women and women with endometrial hyperplasia. Endocr J. 2004;51(6):595-600.

11. Newbold, RR, WR Jefferson, and EP Banks. Longterm Adverse Effects of Neonatal Exposure to Bisphenol A on the Murine Female Reproductive Tract. Reproductive Toxicology. 2007;24:253-8.

12. Duty SM. Phthalate exposure and reproductive hormones in adult men. Hum Reprod. 2005;20:3604-10.

13. Main KM. Human breast milk contamination with phthalates and alterations of endogenous reproductive hormones in infants three months of age. Environ Health Perspect. 2006;114(2):270-6.

14. Lang IA, Galloway TS, Scarlett A. Association of urinary bisphenol a concentration with medical disorders and laboratory abnormalities in adults. JAMA. 2008;300(11):1303-10.

15. Center for the Evaluation of Risks to Human Reproduction (CERHR), NTP-CERHR Monograph on the Potential Human Reproductive and Developmental Effects of Di(2-Ethylhexyl) Phthalate (DEHP), Center for the Evaluation of Risks to Human Reproduction (CERHR), Editor. 2006, National Toxicology Program - US Department of Health and Human Services.

16. Bureau of Indian Standards Draft Indian Standard: Plastics Feeding Bottles First Revision of IS 14625. 2013,Doc:PCD 21( 2662)C.

17. US Food and Drug Administration (FDA). Bisphenol A (BPA): Use in Food Contact Application. Available at: http://www.fda.gov/NewsEvents/PublicHealthFocus /ucm064437.htm.

18. Food Standards Australia New Zealand (FSANZ). Bisphenol A (BPA). May 2016. Available from:http://www.foodstandards.gov.au/consumer/ch emicals/bpa/pages/default.aspx.

19. Creel L. Children's Environmental Health: Risks and Remedies. Population Reference Bureau; 2002 Available

at: http://www.prb.org/pdf/ChildrensEnvironHlth_Eng. pdf.

20. Dona Schneider and Natalie Freeman, Children's Environmental Health: Reducing Risk in a Dangerous World (Washington, DC: American Public Health Association, 2000).

21. ficci.in/spdocument/20396/Knowledge-Paper-ps.pdf

22. Sutton J, Turner B. Plastic bags: Hazards and mitigation. California: Social sciences department, California Polytechnic State University; 2012. Available at: http://digitalcommons.calpoly.edu/cgi/ viewcontent.cgi? article $=1082 \&$ context $=$ socssp. 
23. Sung GB. Ban on plastic bags usage: is it a right move? an empirical study on consumer perception and practice Gelugor; Universiti Sains Malaysia; 2010.

24. Abhigyan. Use of plastic bags: factors affecting ecologically oriented behavior in consumers. Delhi: Foundation for Organisational Research and Education; 2008. Available from: http://www. freepatentsonline.com/article/Abhigyan/192438179. html.

25. Adane L, Muleta D. Survey on the usage of plastic bags, their disposal and adverse impacts on environment: A case study in Jimma City, Southwestern Ethiopia. Journal of Toxicology and Environmental Health Sciences. 2011;3:234-48.

26. Shrestha A, Angolkar M. Improving hand washing among school children: an educational intervention in South India Al Ameen J Med Sci. 2015;8(1):81-5.

27. Rychetnik L, Frommer M, Hawe P. Criteria for evaluating evidence on public health interventions. J Epidemiol Community Health. 2002;56:119-27.

28. Halpern D, Bates C, Aldridge S. Personal responsibility and changing behaviour: the state of knowledge and its implications for public policy. 2004, Cabinet Office, Prime Minister's Strategy Unit Discussion Paper, LondonGoogle Scholar.

29. Gamm L, Castillo G, Williams L. Education and community-based programs in rural areas: a literature review. In: Rural Healthy People 2010: A companion document to Healthy People 2010, Volume 3. Gamm L, Hutchison L, editors. College Station, TX: The Texas A\&M University System Health Science Center, School of Rural Public Health, Southwest Rural Health Research Center; 2004. p.167-86. Available from: http://www.srph.tamhsc.edu/centers/rhp2010/Volum e_3/Vol3Ch4LR.pdf.

30. Institute of Medicine. The future of the public's health in the $21^{\text {st }}$ century. Washington: National Academies Press; 2003.

31. Halpern D, Bates C. Personal responsibility and changing behaviour: the state of knowledge and its implications for public policy. London: Cabinet Office, Prime Minister's Strategy Unit. binet Office, Prime Minister's Strategy Unit. www.strategy.gov.uk/files/pdf/pr.pdf.2004.
32. Jincy Manuel. An educational intervention programme on hazards of plastic waste and its disposal among adults : a rural community based study nitte university. Journal of Health Science NUJHS. 2015;5(2):2249-7110.

33. Yarrow LW, Remig VM, Higgins MM. Food safety educational intervention positively influences college students, food safety attitude, beliefs , knowledge and self-reported practices. J Environ Health. 2009;71(6):30-5.

34. Sandeep KR, Shettigar D, Jayappa S. An educational intervention programme on dengue and its prevention among rural high school children,Karnataka, India. NUJHS. 2014;4(1).

35. What is BPA? http://www.mastercleanse.co.za/ shop.php.

36. Dvorsky G, Bennington-Castro J. How to recognize the plastics that are hazardous to your health, cancerschmancer movement. http:// www.cancerschmancer.org / articles/ howrecognize-plastics-are-hazardous-your-health.

37. Toxic chemical found in feeding bottles ,TNN, 2014 Nov 5. http:// www.timesofindia.indiatimes. com/ city/ delhi/ Toxic-chemical-found-in-feedingbottles/ articleshow/ 45040871.cms

38. Orchard J. There are Different Types of Plastic. The Plastics Gazette. 2009;2(23):314. "http://beyondgoodhealthclinics.com.au/author/dzun g/"Dr. Zung Rosita Vu (Dzung Price).

39. International Obesity TaskForce. Endocrine Disruptors In Common Plastics Linked To Obesity Risk." ScienceDaily. ScienceDaily, 2008 May 18. <www.sciencedaily.com/releases/2008/05/0805140 91427.htm>.

40. Alleyene R. Bisphenol A now linked to male infertility. The Telegraph. 2010,Oct 10. http://www.telegraph.co.uk/ news/ health/ news/ 8093585/ Bisphenol-A-now-linked-to-maleinfertility.html.

41. Wisegeek. Www.wisegeek.com.

Cite this article as: Priya A, Toppo M, Singh D, Singh N, Sethia S. A study to assess the impact of education intervention on the knowledge regarding hazards of plastic food containers in school children. Int J Community Med Public Health 2016;3:2275-80. 